\title{
COMPARATIVE STUDY OF LUMBAR PLEXUS PATH ON THE LEFT AND RIGHT SIDES THROUGH THE PSOAS MUSCLE
}

\author{
ESTUDO COMPARATIVO DO TRAJETO DO PLEXO LOMBAR NOS LADOS DIREITO \\ E ESQUERDO ATRAVÉS DO MÚSCULO PSOAS
}

\section{ESTUDIO COMPARATIVO DEL TRAYECTO DEL PLEXO LUMBAR EN LOS LADOS DERECHO E IZQUIERDO A TRAVÉS DEL MÚSCULO PSOAS}

Emiliano Neves Vialle, ${ }^{1}$ Luiz Roberto Gomes Vialle, ${ }^{1}$ Letícia Cardoso Ern, ${ }^{2}$ Luis Miguel Duchén Rodríguez, 3,4 Grover Coaquira Huayta, ${ }^{4}$ Joana Bretas Cabral Rondon Guasque ${ }^{1}$

\author{
1. Pontifícia Universidade Católica do Paraná, Hospital Universitário Cajuru, Spinal Surgery Group, Curitiba, PR, Brazil. \\ 2. Pontifícia Universidade Católica do Paraná, Curitiba, PR, Brazil. \\ 3. Universidad Pública de El Alto, Department of Anatomy and Neuroanatomy, La Paz, Bolivia. \\ 4. Fellow AOSpine Latin America.
}

\begin{abstract}
Objective: Spine surgery with a minimally invasive lateral approach and validate possible anatomical differences between the right and left sides. Methods: Four measurements $(\mathrm{cm})$ were taken on 38 cadavers: the distance between the lumbar plexus and the transverse process (L4-L5) and the distance between the lumbar plexus and the midline of the lumbar spine, both on the right and left sides. Results: The mean distance between the lumbar plexus and the transverse process of L4-L5 was $1.03 \mathrm{~cm}$ and the distance to the midline was $3.99 \mathrm{~cm}$ for the right side. The averages of the left side were $1.13 \mathrm{~cm}$ and $3.38 \mathrm{~cm}$, respectively. There is statistical difference between the sides $(p<0.05)$ using the non-parametric Wilcoxon test. Conclusions: The authors suggest that the transverse process might be used as an anatomical landmark to define the surgical approach through the psoas muscle. Level of Evidence IV; Cadaveric study.
\end{abstract}

Keywords: Lumbosacral plexus; Spinal fusion; Psoas muscles; Anatomy; Lumbosacral region.

\section{RESUMO}

Objetivo: Encontrar um referencial anatômico prático e seguro durante a cirurgia com a técnica de acesso à coluna ALMI (acesso lateral minimamente invasivo) e validar possíveis diferenças anatômicas entre os lados direito e esquerdo. Método: Foram feitas 4 medidas $(\mathrm{cm})$ em 38 cadáveres: entre o plexo lombar e o processo transverso de L4L5, e entre o plexo lombar e a linha média da coluna lombar dos lados direito e esquerdo. Resultados: A distância média encontrada entre o plexo lombar e o processo transverso de L4L5 foi de $1,03 \mathrm{~cm}$ e a distância até a linha média foi de 3,99 cm do lado direito. Já do lado esquerdo, as médias são 1,13cm e 3,88cm, respectivamente. Houve diferença estatística entre os lados $(p<0,05)$ pelo teste não-paramétrico de Wilcoxon. Conclusão: Sugere-se como referencial anatômico o processo transverso para definir o ponto de entrada do portal de trabalho no músculo psoas. Nível de Evidência IV; Estudo Cadavérico.

Descritores: Plexo lombossacral; Fusão vertebral; Músculos psoas; Anatomia; Região lombossacral.

\section{RESUMEN}

Objetivo: Encontrar una referencia anatómica práctica y segura durante la cirugía de la columna con técnica de abordaje lateral mínimamente invasivo y validar posibles diferencias anatómicas entre los lados derecho e izquierdo. Métodos: Se realizaron 4 medidas (cm) en 38 cadáveres: distancia entre el plexo lumbar y la apófisis transversa (L4-L5) y distancia entre el plexo lumbar y la línea media de la columna lumbar, en los lados derecho e izquierdo. Resultados: La distancia promedio entre el plexo lumbar y la apófisis transversa de L4-L5 fue 1,03 $\mathrm{cm}$ y la distancia a la línea media fue de $3,99 \mathrm{~cm}$ a la derecha. Los promedios de la izquierda fueron 1,13 cm y 3,88 cm respectivamente. Hay diferencia estadística entre los lados $(p<0,05)$ mediante la prueba no paramétrica de Wilcoxon. Conclusiones: Se sugiere como referencia anatómica la apófisis transversa para definir el portal de trabajo a través del músculo psoas. Nivel de Evidencia IV; Estudio cadavérico.

Descriptores: Plexo lumbosacro; Fusión vertebral; Músculos psoas; Anatomía; Región lumbosacra.

\section{INTRODUCTION}

The anterior approach to the lumbar intervertebral disc has several biomechanical advantages over the posterior approach, but also presents technical difficulties in the management of vascular structures not always familiar to the spine surgeon. Lateral access emerged as an alternative to these two approaches, reducing the vascular risk and also offering ample access to the intervertebral disc. With a number of advantages compared to traditional surgery, the minimally invasive lateral approach (MILA) offers reduced tissue trauma, indirect neurological decompression, less blood loss, shorter surgery time, a smaller scar, reduced drug use, and early patient mobility. ${ }^{1-7}$

A part of the technique involves inserting the surgical instrumentation through the psoas major muscle, which may incur some type 
of injury, the most serious of which would be damage to any of the nerve structures that pass inside of it, the lumbar plexus. ${ }^{8}$

The lumbar plexus can be found crossing the fibers of the psoas major muscle. It is part of the lumbosacral plexus and is formed by ventral branches originating from the four primary lumbar nerves with the contribution of the last thoracic branch. They originate as motor and sensory nerves and most of them have both components present. The predominantly motor nerves are the femoral and obturator nerves and the predominantly sensory nerves are the iliohypogastric, genitofemoral, lateral cutaneous, and anterior cutaneous nerves of thigh. ${ }^{1}$

Serious injuries to this plexus can result in denervation and paresthesia, referred to as pain, hyperesthesia, or other abnormalities, such as pseudohernia, in addition to claudication. ${ }^{1,3,9.10}$

It is important to note that the lumbar plexus emerges from the lumbar nerve roots dorsally and close to L4 where it begins to become ventral, the only exception being the genitofemoral nerve, anteriorized in relation to the others. This fact will be important in the surgical approach since safety zones are created for the transpsoas approach and the level most frequently accessed is L4-L5, precisely where the nerve roots move anteriorly. ${ }^{1,5,11}$

There is a specific anatomical relationship between the lumbar plexus and its position within the psoas major muscle, and it remains relatively constant. ${ }^{9}$ However, it is difficult to visualize the location of the nerves of the lumbar plexus with respect to the space of the intervertebral disc from a lateral view, that is, a safe and easily visible reference to assist the surgeon during surgery is lacking. ${ }^{5}$

The objective of this study was to propose a safe and practical anatomical parameter that can be used as a reference in MILA surgeries and to validate the possible anatomical differences between the right and left sides of the lumbar plexus.

\section{METHODS}

The study was conducted by means of measurements of 18 adult cadavers from the anatomy laboratory of the Pontifícia Universidade Católica do Paraná (PUC-PR) and 20 cadavers from the Universidad Pública de El Alto (La Paz, Bolivia) $(n=38)$, taken by 2 evaluators.

Four measurements were taken in centimeters: the distance between the first nerve of the lumbar plexus and the transverse process of the adjacent L4-L5 and the distance between the first nerve of the lumbar plexus and the midline of the spine in L4-L5, both measured on the right and left sides.

The measurements were taken after dissection of the lumbar spine by lateral approach, exposure of the psoas muscle and its elevation, followed by identification of the lumbar plexus and its path over the L4-L5 disc, and measurement using the pachymeter (Figure 1).

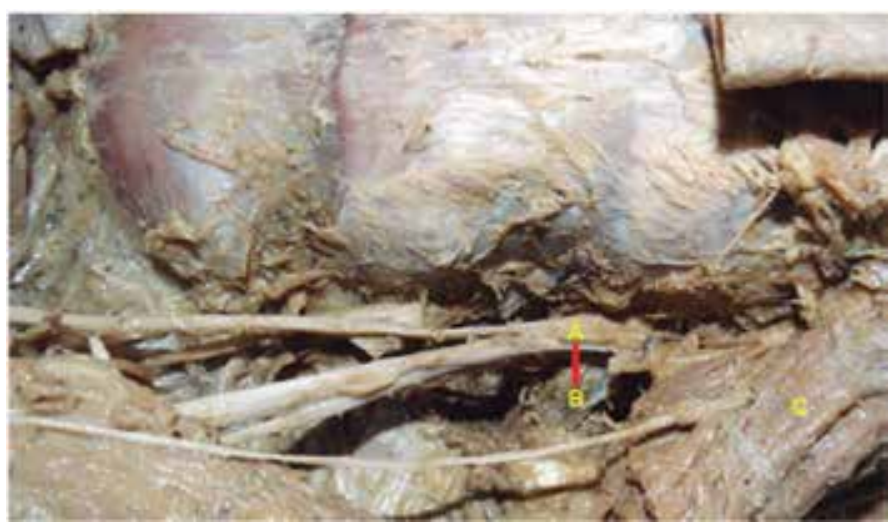

Figure 1. Marking the measurement site. Cadaver in dorsal decubitus with the cephalic region on the right. A indicates the lumbar plexus at its exit, B marks the transverse process of $L 4$, and $C$, the psoas major muscle folded back. The measurement is represented by the line. In the image, the measurement of the left side is being taken. Source: Produced by the author.

\section{RESULTS}

The results of the measurements were described by means, medians, minimum values, maximum values, and standard deviations. The non-parametric Wilcoxon test was used to compare the two sides in relation to the two measurements analyzed. The condition of normality of the variables was evaluated by the Kolmogorov-Smirnov test. Values of $p<0.05$ indicated statistical significance. The data were analyzed with the IBM SPSS Statistics v.20 software.

The results of the measurements and their statistical evaluation can be seen in Table 1.

In 17 of the 38 cadavers evaluated (44.7\%), the measurements of both sides were equal. In 14 (36.8\%), the measurements of the left side were greater than the measurements of the right side and in $7,(18.4 \%)$ the measurements of the right side were greater than the measurements of the left side, as observed in Figure 2.

Table 1. Statistical results in centimeters

\begin{tabular}{c|c|c|c|c|c|c|c}
\hline \multirow{2}{*}{ Side } & \multicolumn{6}{|c|}{ Distance from the lumbar plexus to the L4-L5 } & \multirow{2}{*}{ transverse process } \\
\cline { 2 - 8 } & $\mathbf{n}$ & Mean & Median & Minimum & Maximum & $\begin{array}{c}\text { Standard } \\
\text { Deviation }\end{array}$ & \\
\hline Right & 38 & 1.03 & 0.35 & 0.20 & 2.60 & 0.90 & \\
\hline Left & 38 & 1.13 & 0.35 & 0.20 & 2.60 & 0.98 & \\
\hline $\begin{array}{c}\text { Diff. } \\
\text { (left - right) }\end{array}$ & 38 & 0.10 & 0.00 & -0.20 & 1.60 & 0.29 & 0.020 \\
\hline
\end{tabular}

*Non-parametric Wilcoxon test, $\mathrm{p}<0.05$.

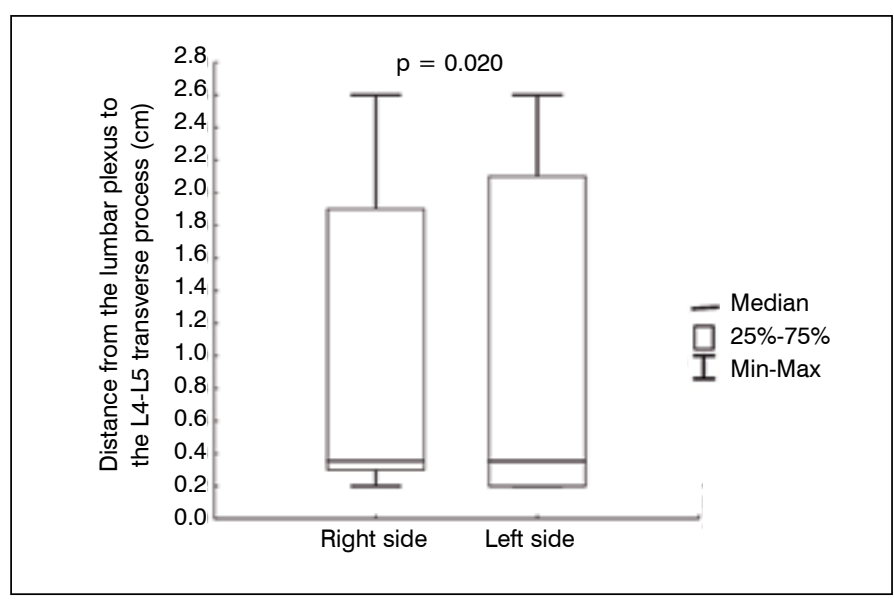

Figure 2. Representation of the distribution of the values of the distance between the lumbar plexus and the transverse process of L4-L5.

\section{DISCUSSION}

There is agreement that the safest approach is in the anterior region of the vertebra. However, few studies determine the exact distance and none define a useful reference during the surgical procedure.

The first study to refer to the anatomical positioning of the lumbar plexus was published in 1996 by Hasegawa et al., who determined for the first time that the lumbar plexus is positioned more anteriorly as it branches out. ${ }^{12}$ Similarly, Moro et al., in 2003 and Benglis et al. in 2009 understood that, because of this anteriorization, the surgical safety zone in L4-L5, when compared to the other spinal safety zones, is much smaller. ${ }^{2,13}$

The first distance was proposed by Regev et al., in 2009, who found a distance of $19.5 \mathrm{~mm}$ between the lumbar plexus and the posterior margin of the terminal plate in L4-L5. ${ }^{11}$ In that study, a safety zone of $20 \mathrm{~mm}$ was defined that was and still is used as a parameter for MILA surgical instrumentation.

Here, it is fitting to question studies, like that of Kepler in 2011, which defined the risk of lesion as $44 \%$ on the right side and $21 \%$ on the 
left side. ${ }^{14}$ With this, it is understood that the value of $20 \mathrm{~mm}$ is clearly overestimated and can lead to more plexus injuries than anticipated.

The distance found in this study is much less, which is consistent not only with clinical studies that evaluate complications, but also with other publications, like that of 2011 by Lu et al. that defined a distance between the lumbar plexus and the transverse process of 0.49 and $0.84 \mathrm{~cm}$ in L4. ${ }^{9}$

The description of each of the studies and their respective results are shown in Table 2.

Notice that most of them, with the exception of 3, do not provide an exact value of where to position the surgical instrumentation. The 3 exceptions are the studies by Regev et al. in 2009, Lu et al. and Kepler et al., both in 2011, who achieved very different results, varying from $2 \mathrm{~cm}$ to less than $1 \mathrm{~cm} \cdot{ }^{11,14-18}$

The method of each study is directly related to its respective results. Studies conducted with magnetic resonance can have significant differences from those with direct measurements in cadavers, which may explain the differences between the values. This study has several limitations, including the small sample size and the method itself that can determine small changes in the measurement due to the position of the pelvis and lower limbs, anatomical dissection, and tissue retraction.
It is understood that the most critical zone for intervention is L4-L5, since the safety corridor is very small (when compared to the others), especially on the right, where there is a risk of nerve lesion posteriorly and lesion of the vena cava anteriorly. In this study, we found values of $1.03 \mathrm{~cm}$ for the right side and $1.13 \mathrm{~cm}$ for the left side as the margins of safety From the transverse process of the closest vertebra. It should be emphasized that on the left, where most approaches are performed, the lumbar plexus is slightly anteriorized and the point of entry for the instrumentation should be anterior to the lumbar plexus. If we consider that in some cases this distance was greater than $2.5 \mathrm{~cm}$, this distance would be the safest region for initiating the dissection of the L4-L5 intervertebral disC and identifying the plexus. In this way, a work area posterior to the lumbar plexus, where the risk of postoperative deficit is high, would be avoided. This safe area can be defined by the arithmetic means of all the measurements (Figure 3).

The statistical analysis showed a statistically significant difference between the right and left sides $(p=0.020)$. Therefore, greater attention and a slight anteriorization of the point of entry in L4-L5 on the left are required.

We suggest the transverse process as a useful and practical surgical reference during the execution of the MILA technique.

Table 2. Results of the main similar studies already conducted

\begin{tabular}{|c|c|c|c|c|c|}
\hline Author & Year & $\begin{array}{l}\text { Study } \\
\text { (Surgery } \mathbf{x} \\
\text { resonance) }\end{array}$ & $\begin{array}{c}\text { Parameter } \\
\text { (Measurement reference) }\end{array}$ & Measurement & Conclusion \\
\hline $\begin{array}{l}\text { hasegawa TMD } \\
\text { et al. }{ }^{12}\end{array}$ & 1996 & $\begin{array}{l}\mathrm{MRI}- \\
20 \text { adults }\end{array}$ & Vertebral pedicle & $\begin{array}{c}\text { The nerves that originate in L4L5 } \\
\text { originate in the middle third of } \\
\text { the pedicle }(65 \%) \text {. }\end{array}$ & $\begin{array}{c}\text { The lumbar plexus of } \mathrm{L} 1 \text { to } \mathrm{L} 5 \text { begins } \\
\text { more dorsally and at } \mathrm{L} 4 \text { begins its } \\
\text { ventralization. }\end{array}$ \\
\hline Moro T et al. ${ }^{13}$ & 2003 & $\begin{array}{l}\text { Cadaver }-30 \text { adult } \\
\text { cadavers }\end{array}$ & $\begin{array}{c}\text { The distance between the } \\
\text { anterior and posterior margins of } \\
\text { the vertebral body was divided } \\
\text { into } 4 \text { equal zones (I, II, III, and } \\
\text { IV). }\end{array}$ & $\begin{array}{c}\text { The lumbar plexus is located in } \\
\text { zone II and below in L4L5. The } \\
\text { genitofemoral nerve was found } \\
\text { in zone I. }\end{array}$ & $\begin{array}{c}\text { The safe working zone is above L4L5, } \\
\text { excluding the genitofemoral nerve } \\
\text { (which is anteriorized before the } \\
\text { others). }\end{array}$ \\
\hline $\begin{array}{l}\text { Benglis DM } \\
\text { et al. }{ }^{2}\end{array}$ & 2009 & $\begin{array}{l}\text { Cadaver - } \\
3 \text { adult cadavers }\end{array}$ & $\begin{array}{l}\text { The relationship between the } \\
\text { location of the plexus in the } \\
\text { posterior terminal plate and } \\
\text { the total length of the disc in } \\
\text { radiographical images. }\end{array}$ & 28\% (L4L5) & $\begin{array}{c}\text { They suggest that the lumbar plexus } \\
\text { begins more dorsally (L1L2) and has } \\
\text { a more ventral direction during its } \\
\text { course, especially in L4L5. Therefore, } \\
\text { there is a higher risk of lesion of the } \\
\text { genitofemoral nerve and the lumbar } \\
\text { plexus. } \\
\end{array}$ \\
\hline $\begin{array}{l}\text { Regev GJ } \\
\text { et al. }{ }^{15}\end{array}$ & 2009 & $\begin{array}{l}\mathrm{MRI}- \\
100 \text { adults }\end{array}$ & $\begin{array}{c}\text { Anterior to posterior margin } \\
\text { of the terminal plate of each } \\
\text { vertebral disc. }\end{array}$ & $19.5 \mathrm{~mm}$ & $\begin{array}{l}\text { The safety zone between L4 and L5 } \\
\text { is quite reduced in comparison to } \\
\text { the other vertebrae (13.1\%). Thus, } \\
\text { an error in posterior interventions } \\
\text { could damage nerves or in anterior } \\
\text { interventions, the blood vessels } \\
\text { (particularly on the right). }\end{array}$ \\
\hline $\begin{array}{l}\text { Uribe JS } \\
\text { et al. }{ }^{16}\end{array}$ & 2010 & $\begin{array}{l}\text { Cadaver - } \\
5 \text { cadavers }\end{array}$ & $\begin{array}{l}\text { The space between the anterior } \\
\text { and posterior margins of the } \\
\text { vertebral body was divided into } \\
4 \text { equal zones. }\end{array}$ & $\begin{array}{l}\text { The lumbar plexus is ideally } \\
\text { located in zones III and IV (L4L5) } \\
\text { and the genitofemoral nerve was } \\
\text { found in zone I. }\end{array}$ & $\begin{array}{c}\text { They suggest that the safe work zone } \\
\text { would be in zone III (posterior middle } \\
\text { fourth) and in L4L5 between zones } \\
\text { II and III. }\end{array}$ \\
\hline $\begin{array}{l}\text { Guérin P } \\
\text { et al. }{ }^{5}\end{array}$ & 2011 & $\begin{array}{c}\text { MRI- } \\
78 \text { adults } \\
\text { between } 30 \text { and } \\
71 \text { years of age. }\end{array}$ & $\begin{array}{l}\text { Dorsal region of the terminal } \\
\text { plate of the vertebral body. }\end{array}$ & $\begin{array}{c}\text { No nerve root was found } \\
\text { anterior to the terminal plate in } \\
37.8 \% .\end{array}$ & $\begin{array}{l}\text { The safe working zone is found in } \\
\text { the most anterior part of the terminal } \\
\text { plate (anterior to the nerves and } \\
\text { posterior to the blood vessels). }\end{array}$ \\
\hline $\begin{array}{l}\text { Kepler KC } \\
\text { et al. }{ }^{14}\end{array}$ & 2011 & $\begin{array}{l}\mathrm{MRI}- \\
43 \text { adults above } \\
50 \text { years of age }\end{array}$ & $\begin{array}{l}\text { A coronal plane in each disc } \\
\text { defined by the line that connects } \\
\text { the anterior margin of the two } \\
\text { adjacent vertebral bodies - } \\
\text { anterior intervertebral plane } \\
\text { (AIP). } \\
\text { AIP to the lumbar plexus }\end{array}$ & $\begin{array}{l}22.1 \mathrm{~mm} \\
\text { (L4L5) }\end{array}$ & $\begin{array}{l}\text { The anterior edge of the psoas } \\
\text { major muscle should be used as a } \\
\text { reference to estimate the position } \\
\text { of the lumbar plexus - when the } \\
\text { anterior edge of the psoas muscle } \\
\text { is } 10 \mathrm{~mm} \text { anterior to the AIP, the } \\
\text { position of the lumbar plexus will be } \\
\text { approximately } 20 \mathrm{~mm} \text { posterior to } \\
\text { the AIP. Patients with neurological } \\
\text { structures at risk were defined as } \\
\text { those who had lumbar plexus/femoral } \\
\text { nerve less than } 20 \text { mm from the } \\
\text { anterior intervertebral plane. }\end{array}$ \\
\hline Lu S et al. ${ }^{17}$ & 2011 & $\begin{array}{c}\text { Cadaver - } \\
15 \text { cadavers from } \\
56 \text { to } 87 \text { years } \\
\text { of age }\end{array}$ & $\begin{array}{l}\text { Lower level of the transverse } \\
\text { process. Division of the psoas } \\
\text { major muscle into } 3 \text { equal thirds. }\end{array}$ & $\begin{array}{l}4.9-8.4 \mathrm{~mm} \\
\quad \text { (L4L5) } \\
\text { Posterior third }\end{array}$ & $\begin{array}{c}\text { The psoas muscle can be considered } \\
\text { a surgical marker, and incisions } \\
\text { should be made in the anterior } 2 / 3 \text {. }\end{array}$ \\
\hline $\begin{array}{l}\text { Spivak JM } \\
\text { et al. }{ }^{18}\end{array}$ & 2013 & $\begin{array}{l}\text { Cadaver - } \\
12 \text { adults } \\
\text { between } 35 \text { and } \\
74 \text { years of age. }\end{array}$ & $\begin{array}{l}\text { Anterior posterior diameter of } \\
\text { each vertebral body (measured } \\
\text { between the anterior edge of } \\
\text { the foramen and the anterior } \\
\text { edge of the vertebral body). }\end{array}$ & $\begin{array}{l}\text { No nerve roots were found in } \\
\text { the anterior } 33 \% \text { of the L } 4 L 5 \\
\text { intervertebral space. }\end{array}$ & $\begin{array}{l}\text { The safe working zone would be the } \\
\text { anterior half of the intervertebral disc. }\end{array}$ \\
\hline
\end{tabular}




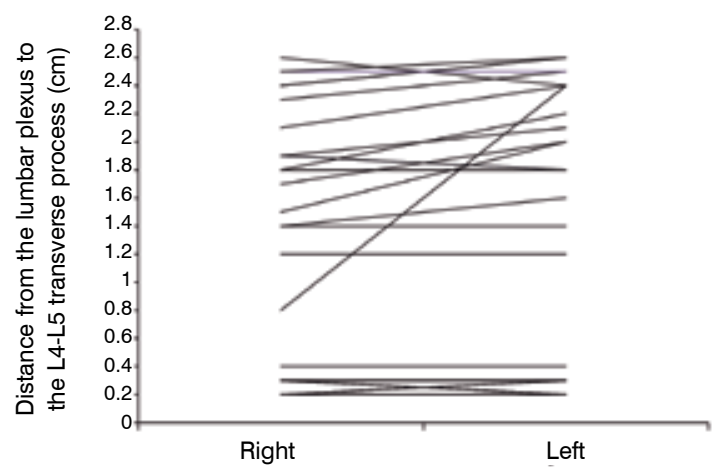

Figure 3. Arithmetic means of the distances found in the study, comparing the right and left sides of each specimen.

\section{CONCLUSIONS}

Defining a safe approach zone is still controversial with regard to a specific value for the positioning of the surgical instrumentation, especially in L4-L5 because of the anteriorization of the plexus at that point in its course.

In this study, we determined that the safe zone is located less than $2 \mathrm{~cm}$ from a fixed point (the transverse process of L4-L5) on both sides, implying that the currently used measures are overestimated. It is understood that there is a statistical difference between the sides. This would be a safe point to initiate exposure of the disc and identify the position of the lumbar plexus, either by direct vision or by intraoperative electromyography.

In addition, we suggest that the transverse process is a practical anatomical reference point for the surgery.

All authors declare no potential conflict of interest related to this article.

CONTRIBUTION OF THE AUTHORS: Each author made significant individual contributions to this manuscript. ENV (0000-0003-1157-4889) ${ }^{\star}$, JBCRG (0000-0001-5057-940X)*, LMDR (0000-0003-4371-2377)*, and GCH (0000-0001-8245-7888)* developed the project structure, performed the anatomical dissections, and participated in the writing of the article. LEC (0000-0003-3042-355X** and LRGV (0000-0002-0638-4311) tabulated the data, reviewed the literature, and participated in the writing and revision of the article. ${ }^{*}$ ORCID (Open Researcher and Contributor ID).

\section{REFERENCES}

1. LeTV, Uribe JS. The Minimally Invasive Retroperitoneal Transpsoas Approach. Spine Surg. 2012;(6):79-96.

2. Benglis DM, Vanni S, Levi AD. An anatomical study of the lumbosacral plexus as related to the minimally invasive transpsoas approach to the lumbar spine. J Neurosurg Spine. 2009;10(2):139-44.

3. Dakwar E, Le TV, Baaj AA, Le AX, Smith WD, Akabarnia BA, Uribe JS. Abdominal wall paresis as a complication of minimally invasive lateral transpsoas interbody fusion. Neurosurg Focus. 2011;31(4):E18.

4. Ozgur BM, Aryan HE, Pimenta L, Taylor WR. Extreme Lateral Interbody Fusion (XLIF): a novel surgical technique for anterior lumbar interbody fusion. Spine J. 2006;6(4):435-43.

5. Guérin P, Obeid I, Gille O, Bourghli A, Luc S, Pointillart V, et al. Safe working zones using the minimally invasive lateral retroperitoneal transpsoas approach: A morphometric study. Surg Radiol Anat. 2011;33(8):665-71.

6. Tohmeh AG, Rodgers WB, Peterson MD. Dynamically evoked, discrete-threshold electromyography in the extreme lateral interbody fusion approach. J Neurosurg Spine. 2011:14(1):31-7.

7. Asgarzadie F, Khoo LT. Minimally Invasive Operative Management for Lumbar Spinal Stenosis: Overview of Early and Long-Term Outcomes. Orthop Clin North Am. 2007:38(3):387-99.

8. Davis TT, Bae HW, Mok JM, Rasouli A, Delamarter RB. Lumbar plexus anatomy within the psoas muscle: implications for the transpsoas lateral approach to the L4-L5 disc. J Bone Joint Surg Am. 2011;93(16):1482-7.

9. Lu S, Chang S, Zhang YZ, Ding ZH, Xu XM, Xu YQ. Clinical anatomy and $3 D$ virtual reconstruction of the lumbar plexus with respect to lumbar surgery. BMC Musculoskelet Disord. 2011;12:76.
10. Lehman RA Jr, Vaccaro AR, Bertagnoli R, Kuklo TR. Standard and minimally invasive approaches to the spine. Orthop Clin North Am. 2005;36(3):281-92.

11. Regev GJ, Kim CW. Safety and the anatomy of the retroperitoneal lateral corridor with respect to the minimally invasive lateral lumbar intervertebral fusion approach. Neurosurg Clin N Am. 2014;25(2):211-8.

12. HasegawaT, MikawaY, Watanabe R, An HS. Morphometric analysis of the lumbosacral nerve roots and dorsal root ganglia by magnetic resonance imaging. Spine (Phila Pa 1976). 1996;21 (9):1005-9

13. Moro T, Kikuchi S, Konno S, Yaginuma H. An anatomic study of the lumbar plexus with respect to retroperitoneal endoscopic surgery. Spine (Phila Pa 1976) 2003:28(5):423-8.

14. Kepler CK, Bogner EA., Herzog RJ, Huang RC. Anatomy of the psoas muscle and lumbar plexus with respect to the surgical approach for lateral transpsoas interbody fusion. Eur Spine J. 2011:20(4):550-6.

15. Regev GJ, Chen L, Dhawan M, Lee YP, Garfin SR, Kim CW. Morphometric analysis of the ventral nerve roots and retroperitoneal vessels with respect to the minimally invasive lateral approach in normal and deformed spines. Spine (Phila Pa 1976). 2009:34(12):1330-5

16. Uribe JS, Arredondo N, Dakwar E, Vale FL. Defining the safe working zones using the minimally invasive lateral retroperitoneal transpsoas approach: an anatomical study. $J$ Neurosurg Spine. 2010;13(2):260-6.

17. Hu WK, He SS, Zhang SC, Liu YB, Li M, Hou TS, et al. An MRI study of psoas major and abdominal large vessels with respect to the X/DLIF approach. Eur Spine J. 2011;20(4):557-62.

18. Spivak JM, Paulino CB, Patel A, Shanti N, Pathare N. Safe zone for retractor placement to the lumbar spine via the transpsoas approach. J Orthop Surg (Hong kong). 2013;21(1):77-81. 